\title{
Accounting
}

\section{The effect of the organizational change on company performance mediated by changes in management accounting practices}

\author{
Nanik Wahyuni ${ }^{{ }^{*}}$ and Boge Triatmanto ${ }^{b}$
}

${ }^{a}$ Faculty of Economics, Universitas Islam Negeri Maulana malik Ibrahim, Malang, Indonesia

${ }^{b}$ Faculty of Economics \& Business, University of Merdeka Malang, Indonesia

\begin{tabular}{l}
\hline C H R O N I C L E \\
\hline Article history: \\
Received March 2020 \\
Received in revised format March \\
292020 \\
Accepted April 72020 \\
Available online \\
April 72020 \\
\hline Keywords: \\
Organizational change \\
Changes in management \\
accounting practices \\
Company performance
\end{tabular}

\section{Introduction}

Performance achievement cannot be separated from the role of management accounting. Changes in management accounting practices are related to several factors in the organizations which are contextual variables either within or outside the company (Moores \& Yuen, 2001) such as environmental uncertainty, strategy, organizational structure, company size, production technology, organizational capacity and competition intensity (Luther \& Longden, 2002). Management accounting is not only a set of techniques, but also a set of values and norms that provide information in the decision-making process, especially for developing manufacturing companies (Tuan Mat et al., 2016). In addition, every part of the company must be consistent and mutually supportive in strengthening management accounting practices, strategies and organizational structures together in order to achieve competitive advantage and the expected performance targets. (Moores \& Yuen, 2001). Manufacturing companies are companies that have complex work capacities, from the production process to finished goods that are ready for sale, using constantly updated technology. Manufacturing companies make a large contribution to gross domestic product (GDP). According to the Central Bureau of Statistics (BPS), there are 4 sectors that contribute greatly ( $>10 \%)$ to GDP per year, while the manufacturing sector only grows $4.2 \%$. This phenomenon is suspected, among others, by the inability of management in anticipating changes occurring in the internal and external environment of the organization. The inability of the management to

\begin{abstract}
This study examines the effect of the organizational change on company performance which is mediated by changes in management accounting practices. High environmental uncertainty requires practices to achieve performance. The study uses a survey method with a total of 1945 respondents as managers of middle to upper manufacturing companies in 389 manufacturing companies in Indonesia analyzing complex models with various indicators that are reflective and formative. The results of the study indicate that organizational change had a positive effect on changes in management accounting changes in management accounting practices are able to mediate environmental changes in performance. Meanwhile, organizational change does not affect the company's performance.
\end{abstract}

(C) 2020 by the authors; licensee Growing Science, Canada
* Corresponding author.

E-mail address: nanik@akuntansi.uin-malang.ac.id (N. Wahyuni) 
anticipate changes is caused by the inability of the company to manage the information available for use in making the right decision.

This research uses the Contingency Theory to explain the relationship between changes within the environment (organization) with management accounting practices in improving performance. Contingency Theory approach in management accounting is based on the premise that there is no universally accepted accounting system that applies equally to all companies. Instead, the accounting system will depend on specific conditions according to the conditions under which a company finds its identity (Waweru \& Uliana, 2016). Changes in management accounting practices internally and in a firms' operations depend on changes in the external environment. This means that the management accounting practices, design, and corporate strategy are strongly influenced by a competitive environment and technological progress. This study aims to analyze the ability to change management accounting practices in mediating the effect of organizational change on company performance. The relationship between contextual variables in Contingency Theory has been carried out by many researchers with a variety of variations and results (Bisbe et al., 2007; Chenhall \& Moers, 2017; Innes \& Mitchell, 1990; Yazdifar \& Tsamenyi, 2005). The variables used in this study are variables of organizational change, changes in management accounting practices and performance. Variable of organizational change with indicators of organizational structure and strategy are considered as contextual factors in companies that have a relationship with changes in management accounting practices (Moores \& Yuen, 2001). If changes in management accounting practices are accompanied by accurate accounting information, it will improve performance (Baines \& Langfieldsmith, 2003). Therefore, organizational performance is an antecedent or the result of changes in management accounting practices.

\section{Literature Review \& Hypothesis}

\subsection{Management Accounting Change (MAC)}

Changes in management accounting practices is a new phenomenon that shows the inequality in the application of management accounting practices in every organization/company. This difference is caused by the factors in the organization that must adjust to the change factors that exist in the company's organizational environment both internally and externally (Quinn, 2011; Tuan Mat et al., 2016; Waweru \& Uliana, 2016). The change process reflects the question of how management accounting practices emerge, develop and change to match new demands on the changing environment in which the company is located. Various types of changes from the perspective of management accounting, among others, are changes in the integration of Activity Based Costing into strategies to manage the organization's operational activities. The results of this study indicate that Activity Based Costing may contribute to improving organizational performance if implemented as a part of an overall organizational change strategy. Some researchers have conducted research related to the changes in management accounting (Baines \& Langfieldsmith, 2003; Bisbe et al., 2007; Robert H. Chenhall \& Euske, 2007; John Innes, Mitchell, \& Sinclair, 2000). Research on the benefits of management accounting changes has been done, but little has been found about the driving forces of these changes (Chenhall \& Euske, 2007; Laitinen, 2014). The results of other studies indicate that one of the drivers of change in management accounting is motivational factors (Baines \& Langfield-Smith, 2003; Bisbe et al., 2007; Laitinen, 2008). The interaction between variables in change is not only in management accounting but also in other related disciplines (Innes \& Mitchell, 1990; Laitinen, 2008). The results of other studies classify the factors that cause changes in management accounting practices in six groups: information needs; technological and environmental changes; the will to change; change resources; purpose of change; and external requirements (Laitinen, 2014). Other researchers also use four categories of factors to explain changes in accounting management, namely: organizational factors; financial factors; motivational factor; and management factor (Laitinen, 2014). Various variables have been associated with changes in management accounting, the variables used in this study are variables of environmental change, organizational change, variable changes in management accounting practices, and organizational performance. Organizational structure and strategy (organizational factors) are considered as contextual factors in a company that may have a relationship with management accounting changes (Moores \& Yuen, 2001). Organizational performance factors are the result of changes in management accounting and changes in organizational structure \& strategy. If there is a change in management accounting supported by accurate accounting information, it will improve performance (Baines \& LangfieldSmith, 2003). In this case, organizational performance is the antecedent or factor resulting from changes in management accounting.

\subsection{Organizational Performance}

Organizational performance is intended as the level of achievement of the organization in carrying out activities in a certain pe riod, usually in one year (van der Steen, 2011). Performance is a reflection of whether an organization or a company has succe eded or not in running a business (Triatmanto et al., 2019). Performance is a factor of management accounting and organizatio nal change. Previous research suggested that there might be a relationship between performance and change (Polnaya et al., 20 18). Performance can be seen from two aspects, namely: qualitative and quantitative. Quantitatively, organizational performan 
ce can be seen from the achievements of the organization compared to what has been done in the past or compared with compe titors in a number of factors, such as net income, stock prices, dividend rates, earnings per share, return on investment, return o $\mathrm{n}$ equity, market share, sales growth, number of workdays lost due to labor strikes, production costs, employee turnover, and e mployee satisfaction index. Qualitative measures, in the form of questions raised to determine the goals, strategies and integrat ed and comprehensive plans of the company are consistent, appropriate and can work or not. Measuring financial performance alone will not always be able to improve performance, because financial measures only show the results of past activities, and there are no guidelines to improve performance in the future, so that we need the support and evaluation of strategic planning (Joiner, Sarah Yang Spencer, \& Salmon, 2009). The use of non-financial information in business units with strategies focusing on customers or models prospector has a positive influence on the performance (Gunasekaran, 2002). The relationship betwee $\mathrm{n}$ strategy with a focus on customers and non-financial performance has no effect on organizational performance (Guerreiro et al., 2006). Therefore, the strategy, action and measurement must be carried out consistently. The use of financial and non-finan cial performance measures is important. If the quality and time are important criteria in strategy measurement, financial perfor mance measures alone are still less effective for the long-term management of the company.

\subsection{Organizational Change}

Change is an important part of management, every organization is always required to adapt to the current conditions in order to be able to survive the change (Laitinen, 2011). Many efforts of change have been made by various organizations and according to the results of the research show that by making changes, organizational performance can progress rapidly (Smith \& Djajadik erta, 2010). But even though it is well planned, organizational change often creates unexpected problems, (Stewart et al., 200 7). The organizational structure is one of the main factors in building an overall control system in carrying out all organization al activities. Management accounting systems are important parts of information and control systems that strengthen and suppo rt the basic objectives of the organizational structure (Moores \& Yuen, 2001). The results of the previous studies indicate that 1 arge companies with sophisticated technology are associated with a decentralized control strategy, whereas small companies u se a centralized control strategy. This shows that when companies are faced with high uncertainty, a decentralized structure is needed so that it impacts on the adoption of a better management accounting system. In addition to the organizational structur e, organizational change can be made through changes in organizational strategy. A strategy is a basis for organizations to inte ract with the environment. Strategy for the organization is a choice of ways or techniques that depend on environmental factors (Sisaye, 2015). The correct relationship between strategy and manufacturing operations is the key to developing a sustainable c ompetitive advantage. A clear business strategy can create value for customers and be different from the competing companies. However, to achieve a competitive advantage, business strategy alone is not enough, but must be supported by appropriate org anizational factors including the effectiveness of manufacturing technology, organizational design and accounting information systems (Jermias \& Gani, 2005). Organizations must change the strategies to accommodate the changing environments. Some researchers have determined that organizational strategies are used to anticipate competitive environments. Appropriate adjust ments to the strategy and environment will improve performance (Baines \& Langfield-smith, 2003; Chenhall \& Euske, 2007).

\subsection{Research Hypothesis}

Changes in management accounting practices are changes that indicate the change within the organization's structure and strat egy (Chenhall, 1998). There are various organizational factors describing the factors of contextual variables inside and outside the company and which have an influence with changes in management accounting practices. The design of Management Acc ounting Systems (MAS) considers strategies and structures to ensure organizational effectiveness in providing information for decision-makers. Several empirical studies have examined the relationship between MAS contingencies, organizational structu re and strategy (Baines \& Langfield-smith, 2003; Chenhall \& Euske, 2007; Moores \& Yuen, 2001). The role of management a ccounting systems is to provide information up-to-date for managers in making economic decisions and to motivate and direct organizational changes. Failure to manage appropriate accounting information can result in ineffective resource management a nd a gradual decline in organizational performance. Changes in the organizational environment cause the need for appropriate changes to maintain effectiveness. Effectiveness of using MAS as the platform for change can be explained by considering the extent to which the organization develops the capacity needed to manage the alignment of changes (Chenhall \& Euske, 2007). Changes in management accounting practices are not always limited to the introduction of new systems (replacement of existin g systems); but can change the way management accounting practices are used (outputs or operational modifications) (Burns \& Scapens, 2000). The forms of change in management accounting practices by utilizing the typology of management accountin $\mathrm{g}$ changes are simple through addition, replacement, modification of output, operational modification and reduction (Sulaiman \& Mitchell, 2005).

$\mathbf{H}_{1}$ : Organizational change has a positive effect on changes in management accounting practices.

Companies that have subsidiaries and have their own responsibilities, usually choose one of two decision-making approaches $t$ o managing company activities, namely: centralization or decentralization. Centralized decision making that is when decisions are made at the top management level, and managers at the lower levels are responsible for implementing those decisions. Dec 
entralized decision making that is, when top managers allow managers at lower levels to make and implement important decisi ons relating to their area of responsibility. Decentralization is the practice of delegating decision-making authority to a lower 1 evel. In today's increasingly competitive competition, decision making carried out must pay attention to factors that provide ad ded value, especially for customers (Bisbe et al., 2007; Guerreiro et al., 2006; Simons, 1987). This focus on customers triggers an organizational structure towards more flat, and reduce a more hierarchical organizational structure. The term "horizontal or ganization" is a revolution in the practice adopted in the company by integrating activities throughout the chain to support cus tomer-focused strategies (Chenhall \& Moers, 2017). In horizontal organizations, decisions are made by cross-functional manag ement teams, including management accountants. A clear business strategy can create value for customers and be different fro $\mathrm{m}$ the competitors (Simons, 1987). However, to achieve competitive advantage, business strategy alone is not enough, but mus $\mathrm{t}$ be supported by appropriate organizational factors including the effectiveness of manufacturing technology, organizational $\mathrm{d}$ esign and accounting information systems (Jermias \& Gani, 2005). Organizations must change strategies to accommodate the c hanging environments. Some researchers have determined that organizational strategies are used to anticipate competitive envi ronments. Appropriate adjustments to the strategy and environment will improve the performance.

$\mathbf{H}_{2}$ : Organizational change has a positive effect on company performance.

Companies must monitor various factors such as price and market share competition, marketing and product competition, num ber of competitors, and competitor actions, which can be achieved through the use of accounting information systems that sup port financial and non-financial performance (Bell \& Hoque, 2009). The use of more advanced management accounting techni ques can help employees to focus more on achieving differentiation strategies, such as quality, delivery, and service to custom ers, to meet customer satisfaction. For example, target costing allows managers to focus on low costs while maintaining custo mer expectations in the dimensions of quality and functionality. The management accounting system is presented as a different iation strategy that can be the basis for the success of a competitive strategy (Seal, 2006).

H3: Changes in management accounting practices have positive effects on company performance.

Market competition and technological progress are the main drivers of management accounting change (Baines \& Langfieldsmith, 2003; Bisbe et al., 2007; Waweru \& Uliana, 2016). In responding to the changing competitive environment, it is important for companies to focus on improving production quality and customer service (Bell \& Hoque, 2009). Previous research states that organizations can change Management Accounting Systems to systems that are more effective and efficient in dealing with high market competition (Baines \& Langfield-Smith, 2003; Haldma \& Lääts, 2002; Hoque, 2001). The introduction of new technology led to a manufacturing cost structure. Computer technology causes direct labor and inventory to disappear from the factory, so the speed of operation is determined by the type of automation and manufacturing system used, and not by how fast the operator can work. As a result, the traditional cost control system itself cannot help managers to manage resources and identify relevant costs. Several studies have shown that there is a relationship between more advanced management accounting practices, such as quality improvement programs, benchmarking and activity-based management with non-financial performa nce. Arguing that there is a positive relationship between management accounting practices in the flexibility of the manufactur ing environment with non-financial performance.

H4: Changes in management accounting practices are able to mediate the effect of organizational change on company performance.

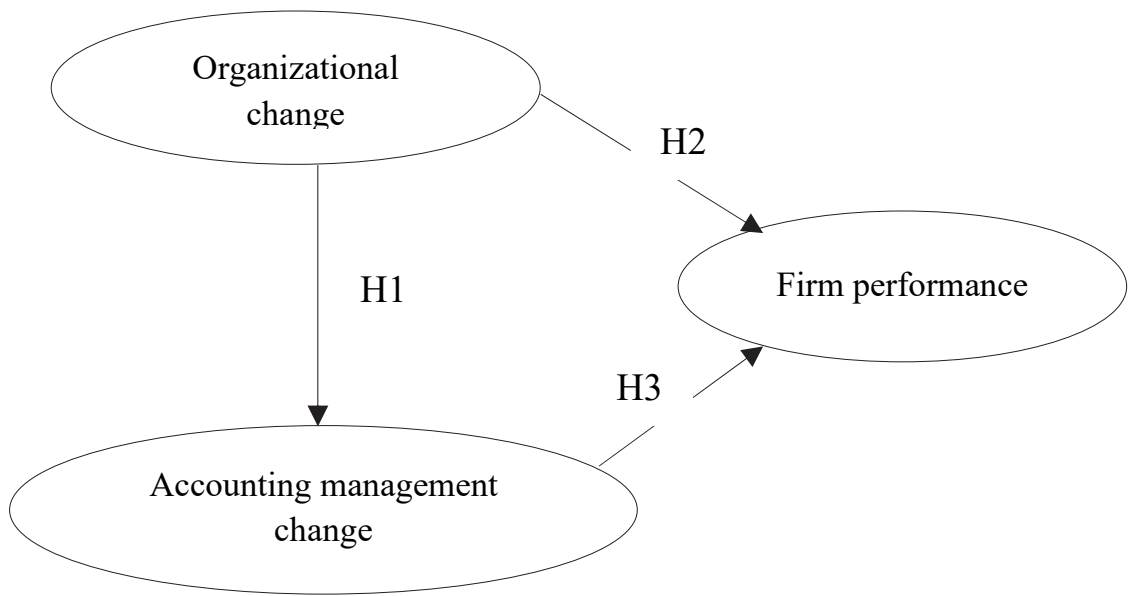

Fig. 1. The proposed study 


\section{Method}

This research is designed to answer the problems that have been formulated. This research is causality based on the problems $\mathrm{t}$ hat arise. This study aims to analyze the direct and indirect effects of organizational change variables on changes in manageme $\mathrm{nt}$ accounting practices and organizational performance. The information to be obtained is the clarity of the occurrence of varia ble relationships built on an equation model based on relevant concepts, so that this study can be classified as explanatory rese arch. This study uses a survey method that is gathering information from quite a large population. This research was conducted with a quantitative approach (positivism) to prove the research hypothesis, the variables studied are quantitative and the data co llection process uses a perceptional approach to facilitate measurement. The population in this study are individuals who work and have mid-level positions and large manufacturing companies in East Java, the managers. The number of manufacturing companies in East Java that carry out production processes and process raw materials into finished goods is 389 companies. The intended unit of analysis is the company, while the observation unit is the individual who works and has an upper middle-level position. Taken five individuals per company so that the total population is 1945 individuals. The analytical tool used to test the hypothesis is Smart Partial Least Square (SmartPLS) software.

\section{Results}

Hypothesis testing is carried to describe the effect of each variable tested using software Smart PLS. The results of testing the effect of organizational change on changes in management accounting practices show a path coefficient of 0.360 with a positive direction and t-statistics of 3.997> 1.96. The positive coefficient has a direct relationship between organizational change and changes in management accounting practices. The results of testing this hypothesis indicate that organizational change has a positive effect on changes in management accounting practices is accepted. The results of testing the effect of organizational change on company performance has a coefficient with a positive direction. The calculation results show that the path coefficient of 0.016 with a t-statistic of $0.176<1.96$ gives the decision that organizational change has no effect on changes in organizational performance. Organizational change as measured by changes in structure and strategy will not always be followed by the organizational performance in both financial and non-financial performance. Hypothesis 2 test results show that organizational change affects the changes in company performance is rejected. The results of testing the effect of changes in management accounting practices on company performance has a coefficient with a positive direction. The calculation results show that the path coefficient of 0.609 with a t-statistic of $8.588>1.96$ provides the decision that changes in management accounting practices affect company performance. Measured changes in management accounting practices from planning, controlling, determining costs, evaluating performance and making decisions will be followed by improvements in company performance in both financial and non-financial performance. Hypothesis 3 test results show that changes in management accounting practices have a positive effect on changes in company performance is accepted. Based on the results of direct influence testing, it can be stated that changes in management accounting practices are directly affected by organizational changes. Organizational performance is directly affected by management accounting practices, but organizational change does not affect organizational performance.

\section{Table 1}

Sobel Test Results on the Hypothesis Model

\begin{tabular}{|c|c|c|c|}
\hline Variable Relationship & Regression coefficient & Standard Error & $\mathrm{T}$ \\
\hline \multicolumn{4}{|l|}{ Direct Influence } \\
\hline Organization $\rightarrow$ Performance & 0.016 & 0.092 & 176 \\
\hline AKM $\rightarrow$ Performance & 0.609 & 0.071 & 8,588 \\
\hline Organizations $\rightarrow$ AKM & 0.360 & 0.089 & 3,997 \\
\hline \multicolumn{4}{|l|}{ Indirect Influence } \\
\hline Organizations $\rightarrow$ AKM $\rightarrow$ Performance & 148 & 0.058 & 2,540 \\
\hline
\end{tabular}

Note: Indirect effects: $\mathrm{a} * \mathrm{~b}$; Standard error $=\sqrt{ }\left(\mathrm{a}^{2} \mathrm{Sb}^{2}+\mathrm{b}^{2} \mathrm{Sa}^{2} \mathrm{Sa}^{2} \mathrm{Sb}^{2}\right.$

The calculated path coefficients in this model explain the magnitude of the direct influence on endogenous variables, namely organizational change, changes in management accounting practices and organizational performance. The direct and indirect effects on the relationship between the two variables are explained in Table 2.

\section{Table 2}

Direct, Indirect and Total Effects

\begin{tabular}{lccc}
\hline Variable Relationship & Direct Influence & Indirect Influence & Total Influence \\
\hline Organizations AKM & 0.360 & - & 0.360 \\
Organizations $\rightarrow$ Performance $\mid$ AKM & 0.016 & $0.360 \times 0.609=0.219$ & 235 \\
AKM $\rightarrow$ Performance & 0.609 & - & 0.609 \\
\hline
\end{tabular}


The fourth hypothesis states that changes in management accounting practices are able to mediate the effect of organizational change on organizational performance. Changes in management accounting practices on organizational performance have a coefficient with a positive direction. The calculation results show that the path coefficient of 0.609 with a t-statistic of 8.588> 1.96 provides the decision that changes in management accounting practices significantly influence organizational performance. Changes in management accounting practices with indicators consisting of planning, controlling, determining costs, reward system and decision making will be followed by improvement in organizational performance in both financial and non-financial components. The path coefficient test results from organizational change to changes in management accounting practices are significant. and the path coefficient from changes in management accounting practices to organizational performance is also significant. Thus, changes in management accounting practices have proven to be able to mediate the effect of organizational change on organizational performance. Because both path coefficients are significant, the results of this test explain that hypothesis 4 is be accepted.

\section{Discussion}

Organizations in carrying out management accounting practices must design organizational structures that fit the organizationa 1 goals. In a good organizational structure, strategies will be developed that are used as a decision-making tool in achieving the goals of the organization. This is very needed in management accounting practices. Companies that make changes in organizat ional structure and strategy have some impacts on changes in management accounting practices. This shows the harmony betw een organizational changes and changes in management accounting practices both in the planning, controlling, cost determina tion, reward system and decision making. This change also impacts the company's performance, both financial and non-finan cial. The results of this study indicate that organizational structure and strategy (organizational factors) are considered as conte xtual factors in companies that have a relationship in changing management accounting practices (Moores \& Yuen, 2001). The results of this research analysis show empirical evidence that organizational change has no effect on company performance. This means that improving company performance does not always occur due to organizational change. Organizational change can occur at any time when the company needs to change. This means that organizational change in manufacturing companies is a basic demand, and this has an effect on improving company performance. The results of this study provide empirical evide nce that changes in management accounting practices will affect company performance. Performance is a result factor of mana gement accounting practices and organizational change. Previous research suggested that there might be a relationship betwee $\mathrm{n}$ performance and changes in management accounting practices. Low financial performance is said to be one of the reasons fo $\mathrm{r}$ companies to change management accounting practices and organizational internal factors to improve the performance (Laiti nen, 2014; Yazdifar \& Tsamenyi, 2005). The role of management accounting systems is to provide updated information to hel $\mathrm{p}$ managers reach informed economic decisions and to motivate users in directing and striving for organizational change (Horn gren, 1995). Failure to rely on appropriate accounting information can contribute to effective resource management and a grad ual decline in organizational performance. Changes in management accounting practices are a new phenomenon in manageme nt accounting that shows the lack of application in each company. This difference is due to the adjustment of changes in the en vironment. Internal and external organizational change factors have influenced the latest developments in management accoun ting practices (Burns \& Scapens, 2000). Furthermore, changes in management accounting practices can improve organizationa 1 performance (Jermias \& Gani, 2005; Tuan Mat et al., 2016; Waweru \& Uliana, 2016). The test results of this study indicate t hat changes in management accounting practices by manufacturing companies, affect the company's performance, both financ ial performance, and non-financial performance. Organizational change influences management accounting practices, so chang es in management accounting practices are able to mediate the effect of organizational change on performance. Improved orga nizational performance through changing management accounting practices with an emphasis on planning. Good planning will produce good management accounting practices and will support improved performance. The positive results of the effect of $\mathrm{c}$ hanges in management accounting practices on improving organizational performance, support the results of research conduct ed by Baines \& Langfield-smith, (2003). The results of this study suggest that if changes in management accounting practices are accompanied by the use of accurate accounting information, it can improve performance. Lee and Yang, (2011), stated that changes in management accounting practices as material for management decision making are able to improve company perfo rmance. Other results suggest a direct relationship between organizational change or changes in management accounting practi ces on performance (Baines \& Langfield-smith, 2003; Choe, 2004). Organizational change that is reflected by changes in orga nizational structure and changes in the strategy implemented, is a change that is influenced by many factors. Changes in organi zational structure and changes in strategy can occur when there is a change in company ownership, changes in company goals or occur events outside the control of the company. Management accounting practices that start from planning, controlling and decision making are very instrumental in achieving company goals. Budget planning, profit, production, and strategic planning must be determined at the beginning of the period for future implementation at a certain time period. Good planning will lead $t$ he company to the targets set. Likewise, the control system implemented by the company has an impact on improving perform ance. In the decision-making process, managers in each section need information from various sources that are accurate throug $\mathrm{h}$ an effective and efficient corporate accounting system. 


\section{Conclusions and Suggestions}

\subsection{Conclusion}

The findings of the study have indicated that organizational change in manufacturing companies in East Java is ongoing and relatively dynamic, whether there is an environmental change or no environmental change. So, the improvement of company/organization performance also does not depend on organizational changes. In addition, organizational change is also able to encourage changes in management accounting practices. The results of the study prove that the success of management accounting practices is caused by the application of appropriate organizational structures and strategies within the company. Existing areas of expertise, commitment, participation, and human resources are well managed in accordance with the company's vision and mission. Organizational change requires companies to be able to change management accounting practices through changes in planning, controlling, determining costs, awarding (evaluating) and decision making processes by adjusting the environmental conditions in which the company is located. Managers must be responsive to competing companies both in terms of products, service to customers, determining costs and selling prices so that the company can still exist. Management accounting practices that can run well will be able to achieve and improve company performance.

\subsection{Suggestion}

This study has several limitations as follows: first, the research model is relatively new, namely the variable of organizational c hange and variable changes in accounting practices as a mediating variable between environmental changes as an independent variable with the performance variable as the dependent variable and can be an advantage in this study, however, to test the co nsistency of the results of the study required re-testing of the model and the relationship between variables. In reflecting the re search variables need to be reviewed with different indicators. The second limitation, response rate post-survey (mail survey) 1 ow. Some returned questionnaires were not filled in by the intended respondent even though the cover letter was addressed to e mployees at the managerial level. It is possible that the questionnaire was sent to another section. Distributing questionnaires w as performed by personally delivering (drop-off delivery) or via couriers, friends or acquaintances who work for the company a nd also through company email.

\section{References}

Baines, A., \& Langfield-Smith, K. (2003). Antecedents to management accounting change: A structural equation approach. Accounting, Organizations and Society, 28(7-8), 675-698.

Bell, J., \& Hoque, Z. (2009). GAOC 2008 conference issue: Accounting's role in organizational change. Journal of Accounting \& Organizational Change, 5(2), 133-138.

Bisbe, J., Batista-Foguet, J. M., \& Chenhall, R. (2007). Defining management accounting constructs: A methodological note on the risks of conceptual misspecification. Accounting, Organizations and Society, 32(7-8), 789-820.

Burns, J., \& Scapens, R. W. (2000). Conceptualizing management accounting change: An institutional framework. Management Accounting Research, 11(1), 3-25.

Chenhall, R. H., \& Langfield-Smith, K. (1998). The relationship between strategic priorities, management techniques and management accounting: an empirical investigation using a systems approach. Accounting, Organizations and Society, 23(3), 243-264.

Chenhall, R. H., \& Euske, K. J. (2007). The role of management control systems in planned organizational change: An analysis of two organizations. Accounting, Organizations and Society, 32(7-8), 601-637.

Chenhall, R. H., \& Moers, F. (2007). The issue of endogeneity within theory-based, quantitative management accounting research. European Accounting Review, 16(1), 173-196.

Choe, J. (2004). information and AMT on organizational. 203-214. https://doi.org/10.1057/palgrave.jit.2000013

Guerreiro, R., Pereira, C. A., \& Frezatti, F. (2006). Evaluating management accounting change according to the institutional theory approach: A case study of a Brazilian bank. Journal of Accounting \& Organizational Change, 2(3), 196-228.

Hussain, M., \& Gunasekaran, A. (2002). Management accounting and performance measures in Japanese banks. Managing Service Quality: An International Journal, 12(4), 232-245.

Haldma, T., \& Lääts, K. (2002). Contingencies influencing the management accounting practices of Estonian manufacturing companies. Management Accounting Research, 13(4), 379-400.

Hoque, Z., Mia, L., \& Alam, M. (2001). Market competition, computer-aided manufacturing and use of multiple performance measures: an empirical study. The British Accounting Review, 33(1), 23-45.

Horngren, C. T. (1995). Management accounting: this century and beyond. Management Accounting Research, 6(3), 281-286.

Innes, J., \& Mitchell, F. (1990). The process of change in management accounting: some field study evidence. Management Accounting Research, 1(1), 3-19. 
Innes, J., Mitchell, F., \& Sinclair, D. (2000). Activity-based costing in the UK's largest companies: a comparison of 1994 and 1999 survey results. Management Accounting Research, 11(3), 349-362.

Jermias, J., \& Gani, L. (2005). Ownership structure, contingent-fit, and business-unit performance: A research model and empirical evidence. International Journal of Accounting, 40(1), 65-85.

Joiner, T. A., Sarah Yang Spencer, X., \& Salmon, S. (2009). The effectiveness of flexible manufacturing strategies: The mediating role of performance measurement systems. International Journal of Productivity and Performance Management, $58(2), 119-135$.

Laitinen, E. K. (2008). A portfolio approach to develop a theory of future management accounting systems. 3(1), $23-37$.

Laitinen, E. K. (2011). Effect of reorganization actions on the financial performance of small entrepreneurial distressed firms. In Journal of Accounting and Organizational Change (Vol. 7). https://doi.org/10.1108/18325911111125540

Laitinen, E. K. (2014). Advances in Accounting, incorporating Advances in International Accounting In fluence of cost accounting change on performance of manufacturing firms. https://doi.org/10.1016/j.adiac.2014.03.003

Lee, C., \& Yang, H. (2011). Organization structure, competition and performance measurement systems and their joint effects on performance. Management Accounting Research, 22(2), 84-104. https://doi.org/10.1016/j.mar.2010.10.003

Luther, R. G., \& Longden, S. (2002). Management accounting in companies adapting to structural change and volatility in transition economies: a South African study. (May 2001), 299-320. https://doi.org/10.1006/mare.2001.0163

Moores, K., \& Yuen, S. (2001). Management accounting systems and organizational configuration: a life-cycle perspective. Accounting, Organizations and Society, 26(4-5), 351-389..

Polnaya, I., Nirwanto, N., \& Triatmanto, B. (2018). The evaluation of lecturer performance through soft skills, organizational culture and compensation on Private University of Ambon. Academy of Strategic Management Journal, 17(2), 1-9.

Quinn, M. (2011). Routines in management accounting research: Further exploration. Journal of Accounting and Organizational Change, 7(4), 337-357.

Seal, W. (2006). Management accounting and corporate governance: An institutional interpretation of the agency problem. Management Accounting Research, 17(4), 389-408.

Simons, R. (1987). Accounting control systems and business strategy: an empirical analysis. Accounting, Organizations and Society, 12(4), 357-374.

Sisaye, S. (2003). Process innovation and adaptive institutional change strategies in management control systems: Activity based costing as administrative innovation. Advances in Management Accounting, 11, 251-286..

Smith, M., \& Djajadikerta, H. (2010). Management Accounting and Organisational Change : An Exploratory Study in Malaysian Manufacturing Firms. Journal of Applied Management Accounting Research, 8(2), 51-80.

Sulaiman, S., \& Mitchell, F. (2005). Utilising a typology of management accounting change: An empirical analysis. Management Accounting Research, 16(4), 422-437.

Triatmanto, B., Wahyuni, N., \& Respati, H. (2019). Continual human resources empowerment through human capital and commitment for the organizational performance in hospitality industry. QUALITY Access to Success, 20(173), 84-91.

Tuan Mat, T. Z., Smith, M., \& Djajadikerta, H. (2016). Determinants of management accounting control system in Malaysian manufacturing companies. Asian Journal of Accounting and Governance, 1(1), 79-104.

van der Steen, M. (2011). The emergence and change of management accounting routines. Accounting, Auditing and Accountability Journal, 24(4), 502-547. https://doi.org/10.1108/09513571111133072

Waweru, N. M., \& Uliana, E. (2016). Predictors of management accounting change in South Africa: Evidence from five retail companies Predictors of management accounting change in South Africa: Evidence from five retail companies. 1954(March). https://doi.org/10.1080/10291954.2005.11435118

Yazdifar, H., \& Tsamenyi, M. (2005). Management accounting change and the changing roles of management accountants: a comparative analysis between dependent and independent organizations. Journal of Accounting \& Organizational Change, 1(2), 180-198. https://doi.org/10.1108/18325910510635353

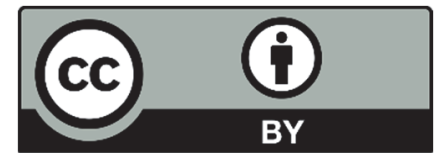

(C) 2020 by the authors; licensee Growing Science, Canada. This is an open access article distributed under the terms and conditions of the Creative Commons Attribution (CC-BY) license (http://creativecommons.org/licenses/by/4.0/). 